\title{
ASSER PRESS
}

Legal Issues of Services of General Interest Series

\section{The EU Services Directive: Law or Simply Policy?}

by

Maria Wiberg

The objective of the EU Services Directive is to realise the internal market for services which is of great importance to the EU and its Member States in respect of facilitating jobs and economic growth. This goal is difficult to achieve without also issues of national social policy, closely related to the welfare state, being affected. This has led to the EU Services Directive exhibiting distinctive features and functions, introducing unique implementation and evaluation procedures and mechanisms to be used by, and within, the Member States. Thus, the Services Directive's characteristics have raised numerous legal questions essential for its full understanding and implementation. It has become a "moving target" for the national administrations. The understanding and implementation of the Services Directive raises several central questions, such as: is it to be interpreted as law or simply policy, and, in light of this, what are its actual effects on the regulatory autonomy of the Member States? In general, does the Services Directive represent a new and innovative instrument which facilitates prosperous integration within the $\mathrm{EU}$ or, has the EU legislator gone beyond its regulatory competence?

This book provides an in-depth analysis of the EU Services Directive, its scope and its application, and clarifies the problems in interpreting the Services Directive and its effects on the national regulatory autonomy of the Member States. It is a valuable source of information for government officials, practitioners and researchers involved in matters of European Law and especially the EU Services Directive.

Maria Wiberg is a Doctor of European Law and Deputy Director at the Swedish Ministry of Foreign Affairs, the Department for the EU Internal Market and the Promotion of Sweden and Swedish Trade, Stockholm, Sweden.

www.asser.nl/AsserPress/?978-94-6265-022-0

ISBN 978-94-6265-022-0

$\mathrm{XV}+311$ p., hardcover, $€ 109.99$

For ordering information (book and eBook) please click: www.springer.com/978-94-6265-022-0 Also available online: http://link.springer.com/978-94-6265-023-7

Distributed for T.M.C. Asser Press by Springer | springer.com 


\section{ASSER PRESS}

\section{Applying International Humanitarian Law in Judicial and Quasi Judicial Bodies \\ International and Domestic Aspects}

\section{Edited by}

Derek Jinks, Jackson N. Maogoto and Solon Solomon

International humanitarian law has been perceived till now as encompassing only judicial cases concerning refugee protection or war crimes prosecutions, particularly in domestic fora. Yet, the last decade has witnessed a revolution in the way judicial bodies - international and domestic alike - are ready to tackle complex security aspects pertaining to the laws of war. The present volume follows the international and domestic courts' jurisprudential evolution as they deal with issues like the classification of armed conflicts, direct participation in hostilities and the nexus between international humanitarian law and human rights law. Projecting the field's jurisprudential development in the future, the volume examines the role of international humanitarian law also in the realms of quasi-judicial bodies.

Derek Jinks, University of Texas, School of Law, Austin, Texas, USA. Jackson Nyamuya Maogoto University of Manchester, School of Law, Manchester, UK. Solon Solomon King's College London, Dickson Poon School of Law, London, UK.

www.asser.nl/AsserPress/?978-94-6265-007-7

ISBN 978-94-6265-007-7

VII, 505 p., hardcover, $€ 129.95$

For ordering information please click: www.springer.com/978-94-6265-007-7 Also available online: link.springer.com/978-94-6265-008-4

Distributed for T.M.C. Asser Press by Springer | springer.com 


\title{
ASSER PRESS
}

\section{The Impact of the European Convention on Human Rights on Private International Law}

\section{by}

\author{
Louwrens R. Kiestra
}

The focus of the present book is the impact of the European Convention on Human Rights (ECHR) on the three main topics of private international law (PIL): jurisdiction, applicable law, and the recognition and enforcement of foreign judgments.

The author sets off with a discussion whether the ECHR is at all applicable to issues of PIL and the relationship between Article 1 of the Convention and PIL. He then examines the case law of the European Court of Human Rights and selected national courts and by doing so thoroughly maps the interaction between PIL and the rights guaranteed in the ECHR. On this wealth of information the author bases his final conclusions.

Next to a list of cases consulted and a comprehensive bibliography, the book offers brief introductions to PIL and the ECHR for readers who are less familiar with either of the topics. This makes the book not only a valuable tool for specialists and practitioners in the fields covered, but at the same time a well-documented basis for students and starting researchers specializing in either or both directions.

Louwrens Kiestra presently works for the District Court Limburg, The Netherlands.

www.asser.nl/AsserPress/?978-94-6265-031-2

ISBN 978-94-6265-031-2

VI+378 p., hardcover, $€ 129.95$

For ordering information please click: www.springer.com/978-94-6265-031-2

Also available online: link.springer.com/978-94-6265-032-9

Distributed for T.M.C. Asser Press by Springer | springer.com 


\section{I4 Volume 6 Issue 2}

\section{Contents}

Articles

Arlinda Rrustemi \& Moritz Baumgärtel, Shooting in the Dark: Evaluating Kosovo's Amnesty Law and the Role of International Actors 115

Pip Nicholson \& Teilee Kuong, Japanese Legal Assistance: An East Asian Model of Legal Assistance and Rule of Law? 141

Tatiana Kyselova, Dualism of Ukrainian Commercial Courts: Exploratory Study 178

M. Forsyth \& B. Haggart, The False Friends Problem for Foreign Norm Transplantation in Developing Countries 202

Deval Desai, Rosie Wagner \& Michael Woolcock, The Missing Middle: Reconfiguring Rule of Law Reform as if Politics and Process Mattered 230

Chao Zhou \& Dan BaniK, Access to Justice and Social Unrest in China’s Countryside: Disputes on Land Acquisition and Compensation 254

Distributed by:

\section{CAMBRIDGE UNIVERSITY PRESS}

\section{Cambridge Journals Online journals.cambridge.org}

